\title{
1. INTRODUCTION AND EXPLANATORY NOTES, DEEP SEA DRILLING PROJECT LEG 631
}

\author{
Robert S. Yeats, Department of Geology, Oregon State University, Corvallis, Oregon \\ Bilal U. Haq, Department of Geology and Geophysics, \\ Woods Hole Oceanographic Institution, Woods Hole, Massachusetts \\ and \\ Kenneth A. Pisciotto, Deep Sea Drilling Project, Scripps Institution of Oceanography, La Jolla, California
}

\section{OBJECTIVES}

Leg 63 of the International Phase of Ocean Drilling began on 9 October 1978 when the Glomar Challenger left Los Angeles harbor and ended on 26 November in Mazatlan, Mexico. This cruise was the first investigation of the region off southern California and Baja California by the Deep Sea Drilling Project. Eleven holes at seven sites were drilled and over 3600 meters of section cored (Figs. 1 and 2, Table 1).

In the North Pacific, the southward-flowing California Current is a major eastern boundary current that has dominated the hydrography off southern California and Baja California since the Cretaceous (Sliter, 1972). Changes in the configuration and intensity of this current throughout the Neogene apparently are reflected in variations in the marine biota locked in sediments of that age (Ingle, 1973). A primary objective of Leg 63 was to investigate the fluctuations of this eastern boundary current along a north-south transect. This information would also aid in biostratigraphically correlating open-ocean planktonic zones with local California zonations.

Spanning the last 30 m.y., the complicated tectonic history of the continental margin off California and Baja California comprises changes from a subduction zone to a transform boundary and then to an inactive margin. A second objective of Leg 63 was to define and clarify this history using information on sedimentation, unconformities, basement ages, and paleomagnetic reconstructions gained from drilling, in conjunction with geophysical data and pre-existing bottom samples.

At several sites we expected to recover Miocene sediments rich in organic matter. A third objective of Leg 63 drilling was to investigate the degree and mode of diagenesis of this organic matter under conditions of shallow burial and low temperature. This information would be useful in evaluating diagenetic pathways of organic matter in similar sediments and sedimentary rocks that are important hydrocarbon sources onshore.

\section{OPERATIONAL SUMMARY}

The Glomar Challenger departed Long Beach, California on 9 October 1978 after a stay in dry dock at

\footnotetext{
${ }^{1}$ Initial Reports of the Deep Sea Drilling Project, Volume 63.
}

the port of San Pedro. The first site (467) was located using a multichannel line of the S.P. Lee and a singlechannel line of the Bartlett. Coring was routine to total depth, except for the occurrence of $\mathrm{H}_{2} \mathrm{~S}$ and low molecular-weight hydrocarbon gases $\left(C_{1}\right.$ and $\left.C_{2}\right)$, which were monitored with the gas chromatograph. Once hard, tuffaceous sediments were reached at 745 meters, $\mathrm{C}_{1}$ and $\mathrm{C}_{2}$ dropped, and further monitoring did not reveal any significant amounts of hydrocarbon gases. A Sonic and Caliper Log was run, but the succeeding Temperature-Density Log encountered hole bridging, and we abandoned the hole after plugging it with cement. One of the bow thrusters developed problems at Site 467 , requiring a return to Long Beach for repairs.

The Challenger arrived at Long Beach on 18 October and departed on 20 October after replacement of the thruster gearbox. Site 468 was located on a slope of the Patton Ridge using a single-channel E.P. Scripps line and a multichannel line of the S.P. Lee. Coring was routine to a depth of 200 meters, below which torquing and pipe-sticking increased, owing to sloughing of sand and volcanic fragments. As a result, Hole 468 was abandoned at a depth of 241 meters, and Hole $468 \mathrm{~A}$ was spudded a short distance upslope. After Core 4 was cut, a break in the sand line made it necessary to abandon the hole and spud Hole 468B. Coring was continuous to 111.5 meters depth in this hole, below which cores were taken at alternate 9.5-meter intervals, because the section was essentially the same as that at Hole 468. Below 197.0 meters, continuous coring resumed. Coring was terminated at $\mathbf{4 1 5 . 5}$ meters because of uncertainty regarding the depth to basement indicated by the site survey. Logging was unsuccessful owing to problems with the logging sondes and with the computer in the logging cab.

The short trip to Site 469 involved the use of the 120 -cubic-in. air gun to provide enough energy to penetrate the $0.5 \mathrm{~s}$ of sediment section above basement indicated on a 1976 single-channel line and a 1978 multichannel line, both run by the S.P. Lee. An excellent basement record was obtained at 5.5 knots. Coring was routine except that the core barrel was retrieved using the drawworks sand line instead of the regular sand line, thereby shortening the time necessary to retrieve each core. Coring terminated upon destruction of the bit in basalt. Logging was not possible because of a failure of the bit-release tool. On leaving the site, an attempt was 


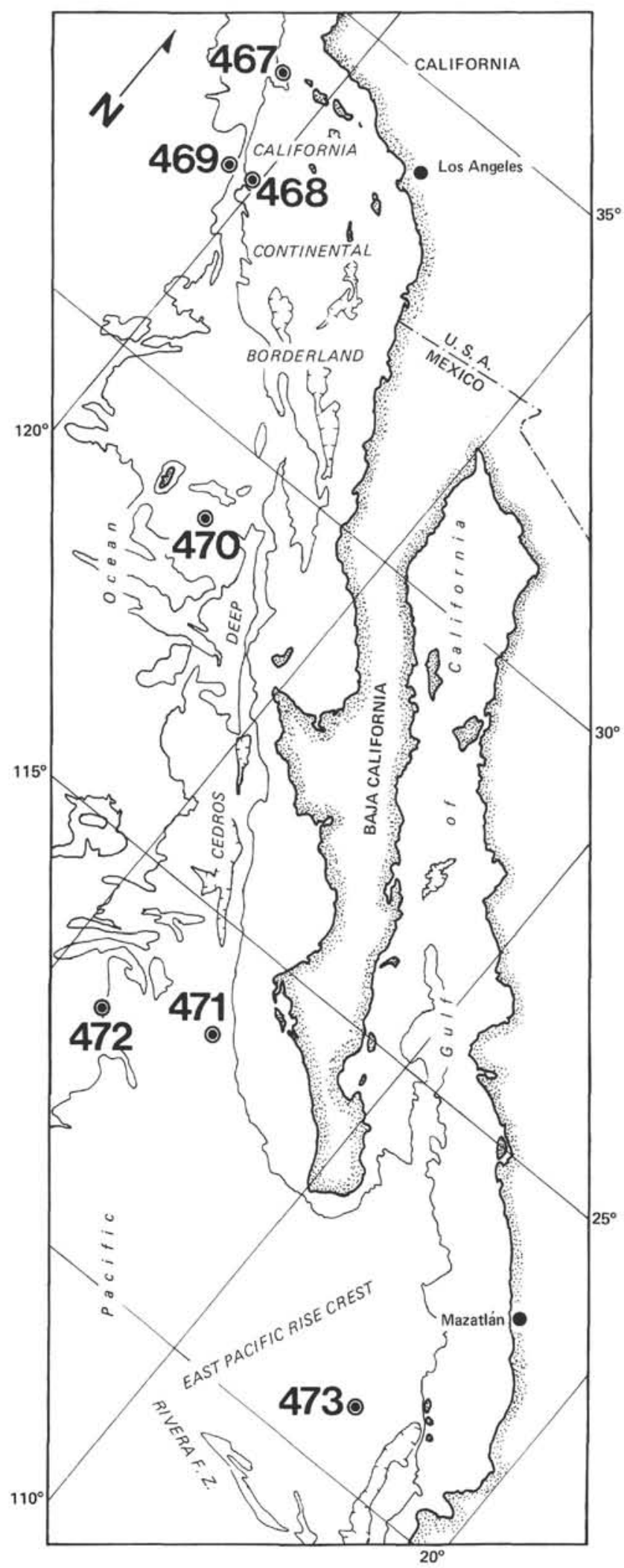

Figure 1. Location of Leg 63 sites. made to trace the basement reflector to the Patton Escarpment by surveying with the 120 -cubic-in. air gun at 5.5 knots, but the reflector could be traced only part way.

Site 470 was located $8 \mathrm{~km}$ south-southwest of the Experimental Mohole Site near Guadalupe Island. Coring was routine to bit destruction in basalt. Because of low recovery in the upper Miocene to lower Pliocene section in Hole 470, Hole 470A was continuously cored from 47.5 to 95 meters. Logging was unsuccessful because the logging tool could not clear the end of the pipe at 63 meters depth, probably the result of poorly consolidated sediment at that depth.

The track from Site 470 to Site 471 was designated to determine the relations of both sites to the continental slope off Baja California. Accordingly, a slightly zigzag course was taken to cross the Cedros Deep twice and then to survey across Site 471 to the foot of the continental slope south of Magdalena Bay. Coring was continuous to bit destruction in diabase, and the heat-flow probe was run at 95 and 142.5 meters. (Criteria for running the heat-flow probe were that the sediment be firm enough to take weight but not so hard that the probe would be unable to penetrate it.) Before logging, the pipe was raised to 158 meters below the mudline to avoid hole bridging in unconsolidated sediments (which occurred at Site 470). Logs included the Sonic-CaliperGamma Ray Log, variable Density-Sonic (Wave-Train) Log, Temperature-Density-Gamma Ray Log, GuardNeutron-Gamma Ray Log, Induction-Gamma Ray Log and, finally, a Temperature Log. The hole was cemented because of occasional gas shows in the cores.

At this point we were ahead of schedule, and we needed a site at the latitude of Site 471 that was undiluted by terrigenous sediments. Accordingly, we traveled west to a point (Site 472) where the crust had been dated by magnetic-anomaly stripes and spudded Hole 472. Coring was continuous to bit destruction in basalt, and a heat-flow measurement was taken at 88 meters. We encountered basalt before we could take a second heat-flow measurement; we therefore spudded Hole $472 \mathrm{~A}$ to take a second, deeper heat-flow measurement. Basalt was encountered at a depth 17.5 meters shallower than in Hole 472, however, and the site was abandoned.

At Site 473, we cored continously to bit destruction in basalt. Heat-flow measurements were made at depths of $67,105,143,181.5$, and 219 meters; anomalously high readings at 105 and 219 meters depth may have been the result of hole friction. After coring, the bit was released, and the pipe was raised to 132.5 meters below the mudline for logging. But a sediment bridge at 185 meters prevented logging.

\section{RESPONSIBILITIES FOR AUTHORSHIP}

Chapters 2 through 8 in Part I of this volume present the basic shipboard data and discussion on the holes drilled during Leg 63. The authorship of these site chapters is collectively that of the shipboard scientific 
party, but ultimate responsibility lies with the Co-Chief Scientists, Bilal Haq and Robert Yeats. Each chapter was compiled according to the standard format listed here (the names of the authors of each section are given in parentheses):

Background and Objectives (Yeats and Haq)

Operations (Yeats and Haq)

Lithology-Sediments and Igneous Rocks (Crouch, Grechin, Leinen, Niem, Pal, Pisciotto, Shibata)

Biostratigraphy (Barron, Bukry, Poore, Wolfart)

Nannofossils (Bukry)

Silicoflagellates (Bukry)

Radiolarians (Wolfart)

Diatoms (Barron)

Planktonic Foraminifers (Poore)

Sediment Accumulation Rates (Barron, Bukry,

Poore, Wolfart)

Inorganic Geochemistry (Leinen)

Physical Properties and Downhole Logs (Pisciotto)

Correlation of Drilling Results and Seismic Data (Crouch)

Conclusions (Yeats and Haq)

\section{EXPLANATORY NOTES}

\section{Numbering of Sites, Holes, Cores, and Samples}

DSDP drill sites are numbered consecutively from the first site at which the Glomar Challenger drilled in 1968. Hole numbers are not identical with site numbers. A site number refers to the location of one or more holes drilled while the ship was positioned over one acoustic beacon; these holes may be located within a radius as great as 900 meters from the beacon. Several holes may be drilled at a single site by pulling the drill pipe above the sea floor (out of one hole), moving the ship 100 meters or more from the previous hole, and then drilling another hole.

The first (or only) hole drilled at a site takes the site number. A letter suffix distinguishes each additional hole at the same site. For example, the first hole takes only the site number, the second takes the site number with suffix $A$, the third takes the site number with suffix B, and so forth. It is important, for sampling purposes, to distinguish the holes drilled at a site, because recovered sediments or rocks from different holes usually do not come from equivalent positions in the stratigraphic column.

The cored interval is measured in meters below the sea floor. The depth interval of an individual core is the depth below the sea floor at which the coring operation began to the depth at which the coring operation ended. Each coring interval is generally 9.5 meters long, which is the nominal length of a core barrel; however, the coring interval may be shorter or sometimes slightly longer. "Cored intervals" are not necessarily adjacent to each other, but may be separated by "drilled intervals." In soft sediment, the drill string may be "washed ahead" with the core barrel in place, but not recovering sediment, by pumping water down the pipe at high pressure to wash the sediment out of the way of the bit and up the space between the drill pipe and wall of the hole. If thin hard rock layers are present, however, then it is possible to get "spotty" sampling of these resistant layers within the washed interval and thus have a cored interval greater than 9.5 meters.

Cores taken from a hole are numbered serially from the top of the hole downward. Core numbers and their associated cored intervals in meters below the sea floor are normally unique for a hole, however, problems may arise if an interval is cored twice. When this situation occurs, the core number is assigned a suffix, such as " $S$ " for supplementary. ${ }^{2}$

Full recovery for a single core is normally 9.28 meters of sediment or rock that is in a plastic liner, the inside diameter of which is $6.6 \mathrm{~cm}$, plus about a 0.2 -meter-long sample (without a plastic liner) in the core-catcher. The core-catcher is a device at the bottom of the core barrel that prevents the cored sample from sliding out when the barrel is retrieved from the hole. The core is then cut into 1.5-meter-long sections and numbered serially from the top of the core (Fig. 3). When we obtain full recovery, the sections are numbered from 1 through 7 , with the last section shorter than 1.5 meters. The corecatcher sample is placed below the last section when the core is described and labeled core-catcher (CC); it is treated as a separate section.

When there is only partial recovery, the original stratigraphic position of the material in the cored interval is unknown. If the recovered material is contiguous, the top of this material is identified as the top of the cored interval; and 1.5-meter sections-as many as needed to accommodate the length of this interval-are numbered beginning with Section 1 at the top (Fig. 3). ${ }^{3}$ For example, 4 meters of material are divided into three sections, two upper sections each 1.5 meters long and a final lower section only 1.0 meter in length. If the material recovered is not contiguous, as determined by the shipboard scientists, then sections are divided and numbered serially, as with contiguous material, and gaps are labeled as voids for sediments (Fig. 3) or marked by spacers for igneous rocks (see the section on Igneous Rocks).

Samples are designated by centimeter distances from the top of each section to the top and bottom of the sample in that section. A full identification number for a sample consists of the following information: leg-sitehole-core number-section number, interval (in $\mathrm{cm}$ from the top of the section). For example, a sample identification number of " $63-468 \mathrm{~B}-9-3,12-14 \mathrm{~cm}$ " is interpreted as follows: 12 to $14 \mathrm{~cm}$ designates a sample taken at 12 to $14 \mathrm{~cm}$ from the top of Section 3 of Core 9, from the third hole drilled at Site 468 during Leg 63 . The depth of this sample below the sea floor is the summation of the following: (1) the depth to the top of the cored interval for Core 9 , which is 92.5 meters; (2) plus

\footnotetext{
${ }^{2}$ Note that this designation has been used on previous legs as a prefix to the core number for sidewall core samples.

${ }^{3}$ This technique differs from the labelling system used on Legs 1 through 45 , which have a designation called "zero section," but do not have a "number 7 section."
} 


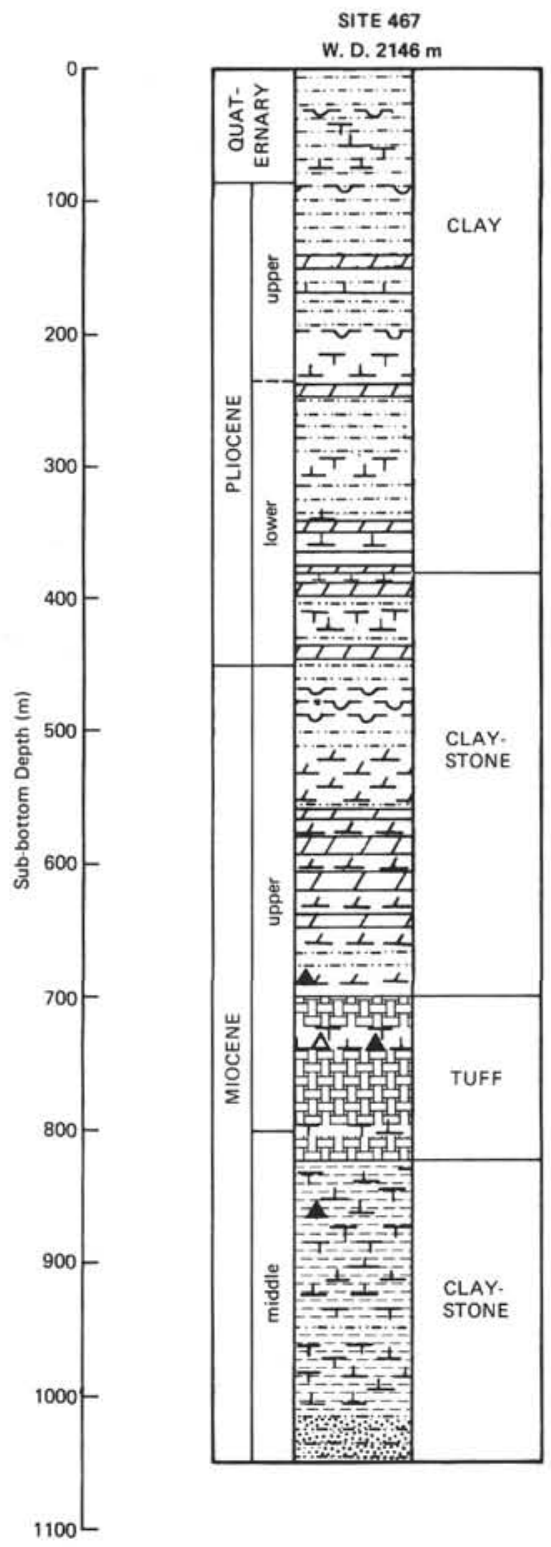

CALIFORNIA CONTINENTAL BORDERLAND
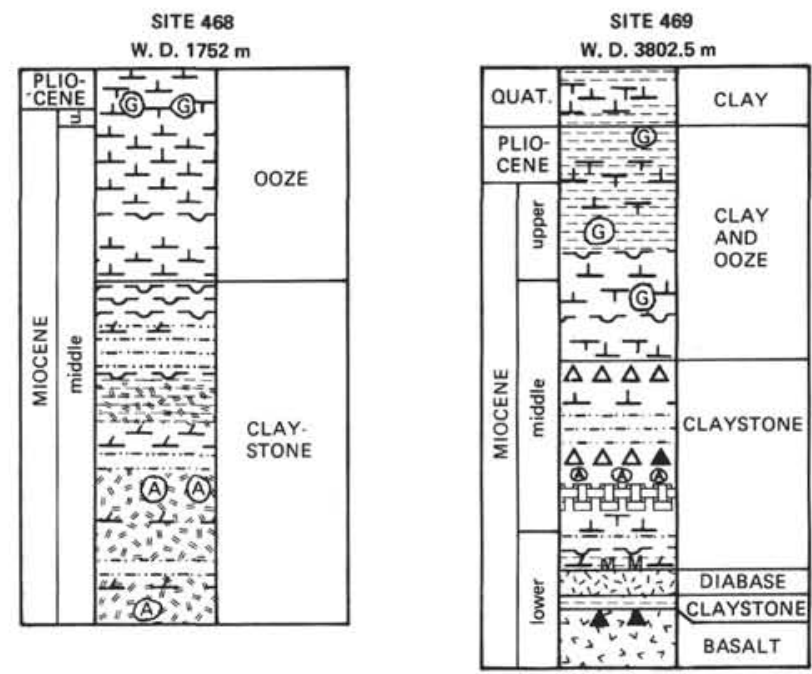

Figure 2. Stratigraphic summary of Leg 63 sites. (Water depth [W.D.] is measured from drill pipe.)

3 meters for Sections 1 and 2 (each 1.5 meters long); (3) plus the $12 \mathrm{~cm}$ depth below the top of Section 3. All of these variables add up to 95.62 meters. ${ }^{4}$

\section{Handling of Cores}

A core is normally cut into 1.5 -meter sections, sealed, labeled, and brought into the core laboratory for processing. Gas analyses and continuous wet-bulk density determinations using the Gamma Ray Attenuation Porosity Evaluator (GRAPE) are made before splitting the sections.

The cores are then split longitudinally into "working" and "archive" halves. Samples are taken from the "working"' half, including those for determination of

${ }^{4}$ Sample requests should refer to a specific interval within a section of core, rather than a total depth below sea level. grain-size distribution, mineralogy by x-ray diffraction, sonic velocity by the Hamilton Frame method, wet-bulk density by a static GRAPE technique, water content by gravimetric analysis, carbon-carbonate analysis, calcium-carbonate percentage ("Karbonat Bombe"), geochemical analysis, paleontological studies, and others. Smear slides (thin sections for lithified sedimentary and igneous rocks) from each major lithology, and most minor lithologies, are prepared and examined microscopically. The archive half is then described and photographed. Physical disturbance by the drill bit, color, texture, structures, and composition of the various lithologies are noted on standard Core Description Forms (see the following section).

After the cores are sampled and described, they are maintained in cold storage aboard the Glomar Challenger until they can be transferred to the DSDP repos- 
WESTERN CONTINENTAL MARGIN OF MEXICO

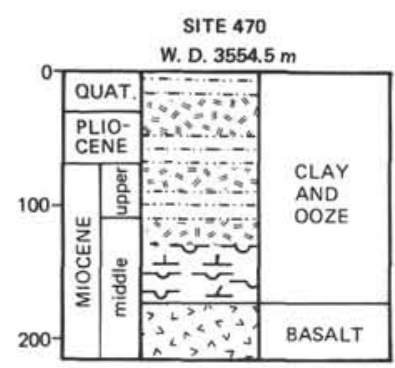

SITE 471

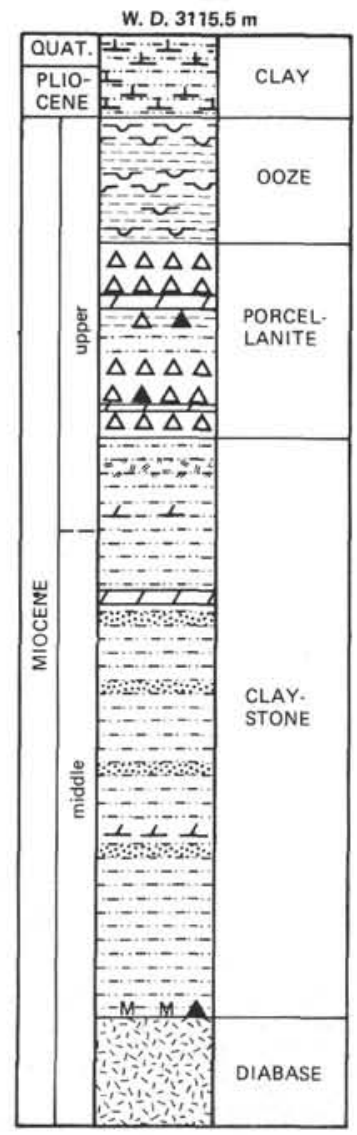

SITE 472

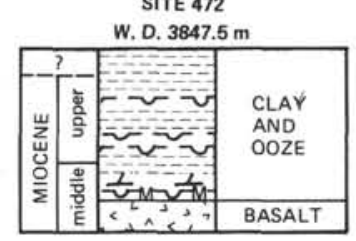

ए土工

TTT TIT FORAMINIFER

TTTT TOZE

= $=$ JDIATOM

$\triangle \triangle \triangle$ PORCELLANITE

\begin{tabular}{l|l}
$\Delta \Delta \Delta$ & PORCEL \\
\hline$\Delta \Delta$ & CHERT
\end{tabular}

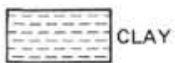

SILTY CLAYSTONE,
CLAYEY SILTSTONE

L $\perp$ CALC./DOLOMITIC

$\leftarrow \perp \perp-1$ CLAYC./DOLOMTONE

, ADOLOMITE/DOLOMITIC
SITE 473

W. D. $3267.5 \mathrm{~m}$

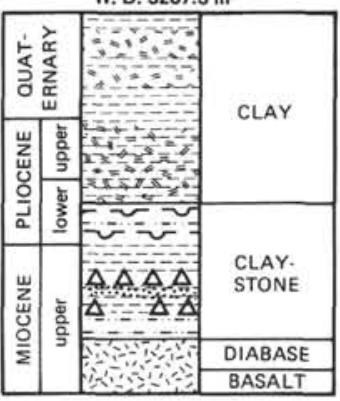

SANDSTONE

(C) (G) G GLAUCONITE

M M M M METALLIFEROUS $\because \because \because \because$ VOLCANIC

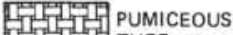
패묘맥 TUFF

起是貝DIABASE

(A) A $\begin{aligned} & \text { ANDESITIC } \\ & \text { BRECCIA }\end{aligned}$

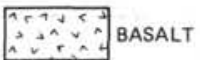

Figure 2. (Continued).

Table 1. Leg 63 coring summary.

\begin{tabular}{|c|c|c|c|c|c|c|c|c|c|}
\hline Hole & $\begin{array}{l}\text { Dates } \\
(1978)\end{array}$ & Latitude & Longitude & $\begin{array}{l}\text { Water } \\
\text { Depth } \\
\text { (m) }\end{array}$ & $\begin{array}{l}\text { Penetration } \\
\text { (m) }\end{array}$ & $\begin{array}{l}\text { Numbers } \\
\text { of Cores }\end{array}$ & $\begin{array}{l}\text { Meters } \\
\text { Cored }\end{array}$ & $\begin{array}{c}\text { Meters } \\
\text { Recovered }\end{array}$ & $\begin{array}{c}\text { Core } \\
\text { Recovered } \\
(\%)\end{array}$ \\
\hline 467 & 10-18 October & $33^{\circ} 50.97^{\prime} \mathrm{N}$ & $120^{\circ} 45.47^{\prime} \mathrm{W}$ & 2127.8 & 1041.5 & 110 & 1041.5 & 426.30 & 41 \\
\hline 468 & 21-23 October & $32^{\circ} 37.03^{\prime} \mathrm{N}$ & $120^{\circ} 07.07^{\prime} \mathrm{W}$ & 1849.0 & 241.0 & 26 & 241.0 & 83.74 & 34 \\
\hline $468 \mathrm{~A}$ & 23-24 October & $32^{\circ} 37.41^{\prime} \mathrm{N}$ & $120^{\circ} 06.55^{\prime} \mathrm{W}$ & 1737.0 & 35.5 & 4 & 35.5 & 27.68 & 78 \\
\hline 468B & 24-26 October & $32^{\circ} 37.41^{\prime} \mathrm{N}$ & $120^{\circ} 06.55^{\prime} \mathrm{W}$ & 1737.0 & 415.5 & 37 & 351.5 & 104.58 & 30 \\
\hline 469 & 27 Oct.-1 Nov. & $32^{\circ} 37.00^{\prime} \mathrm{N}$ & $120^{\circ} 32.90^{\prime} \mathrm{W}$ & 3790.0 & 453.5 & 51 & 453.5 & 178.46 & 39 \\
\hline 470 & 2-4 November & $28^{\circ} 54.46^{\prime} \mathrm{N}$ & $117^{\circ} 31.11^{\prime} \mathrm{W}$ & 3549.0 & 168.0 & 18 & 168.0 & 90.02 & 54 \\
\hline $470 \mathrm{~A}$ & 4-6 November & $28^{\circ} 54.46^{\prime} \mathrm{N}$ & $117^{\circ} 31.11^{\prime} \mathrm{W}$ & 3549.0 & 215.5 & 13 & 101.5 & 48.21 & 47 \\
\hline 471 & 8-17 November & $23^{\circ} 28.93^{\prime} \mathrm{N}$ & $112^{\circ} 29.78^{\prime} \mathrm{W}$ & 3101.0 & 823.0 & 88 & 823.0 & 356.40 & 43 \\
\hline 472 & $18-19$ November & $23^{\circ} 00.35^{\prime} \mathrm{N}$ & $113^{\circ} 59.71^{\prime} \mathrm{W}$ & 3831.0 & 137.5 & 16 & 137.5 & 65.11 & 47 \\
\hline $472 A$ & $19-20$ November & $23^{\circ} 00.35^{\prime} \mathrm{N}$ & $113^{\circ} 59.71^{\prime} \mathrm{W}$ & 3831.0 & 94.5 & 1 & 0.2 & 0.20 & 100 \\
\hline \multirow[t]{2}{*}{473} & 22-26 November & $20^{\circ} 57.92^{\prime} \mathrm{N}$ & $107^{\circ} 03.81^{\prime} \mathrm{W}$ & 3249.0 & 287.5 & 34 & 287.5 & 142.07 & 49 \\
\hline & & & & & Total & 398 & 3640.7 & 1522.78 & 42 \\
\hline
\end{tabular}

a Water depth from sea level. 


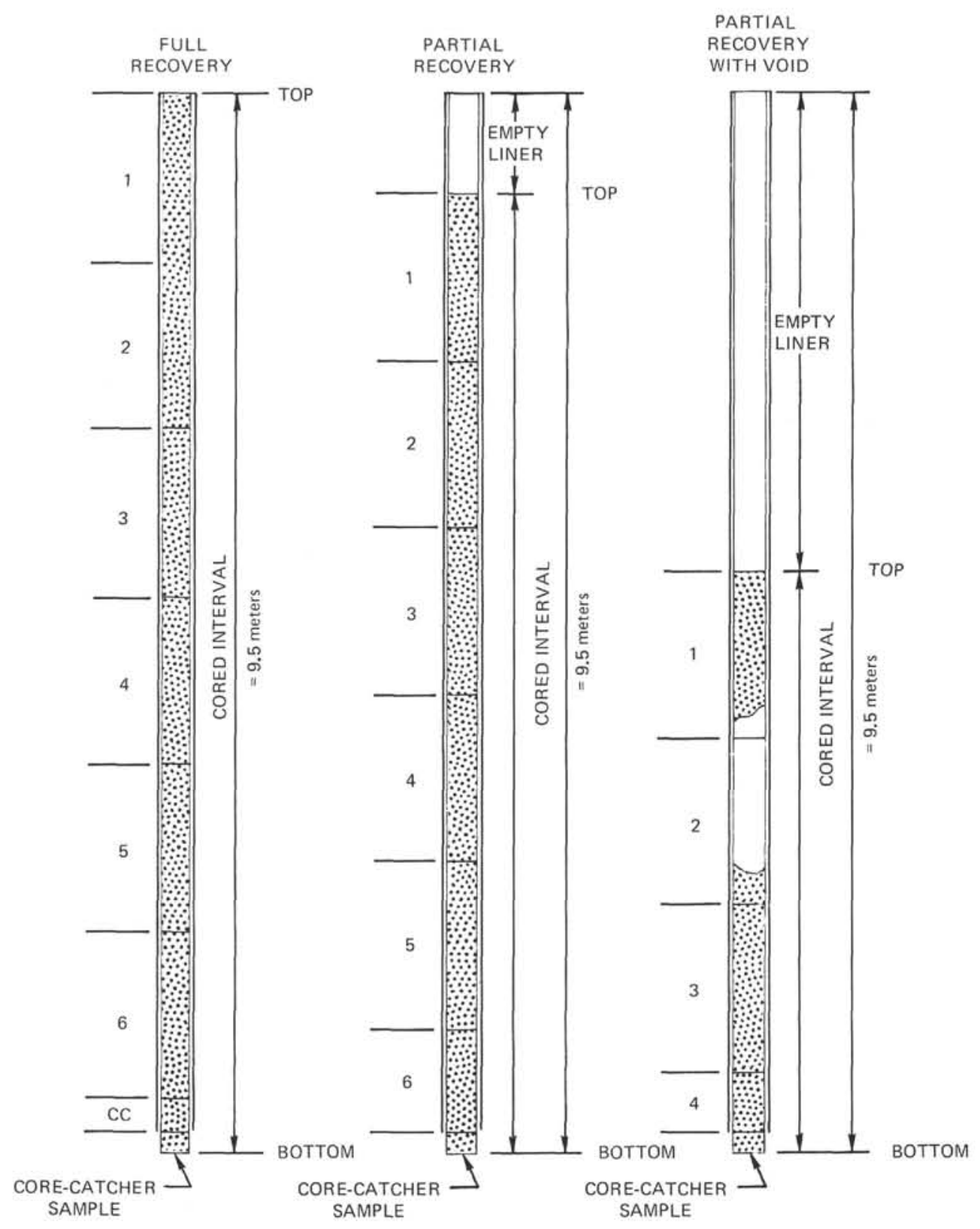

Figure 3. DSDP procedures for cutting and labeling core sections.

itory. Core sections of sediments removed for organic geochemistry study are frozen immediately on board ship and kept frozen. All Leg 63 cores and frozen cores are presently stored at the DSDP West Coast Repository (Scripps Institution of Oceanography).

\section{Sediments and Sedimentary Rocks}

\section{Core Description Forms}

Recovered rocks, particularly the soft sediments, may be extremely disturbed. This mechanical disturbance is the result of the coring technique, which uses a large $25-\mathrm{cm}$-diameter bit with a small 6.0 -cm-diameter opening for the core sample. The following disturbance categories are used for soft and firm sediment:

Slightly deformed: bedding contacts are slightly bent.
Moderately deformed: bedding contacts have undergone extreme bowing.

Very deformed: bedding is completely disturbed or homogenized by drilling, sometimes showing symmetrical diapirlike structure.

Soupy: The intervals are water-saturated and have lost all aspects of original bedding.

These categories appear on the Core Description Form (Fig. 4) in the column headed "Drilling Disturbance."

In soft and in some harder sediments it may be extremely difficult to distinguish between natural structures and structures created by the coring process. Structures listed on the core forms for soft lithologies are therefore somewhat tentative. Locations and types of these structures appear as graphic symbols in the col- 


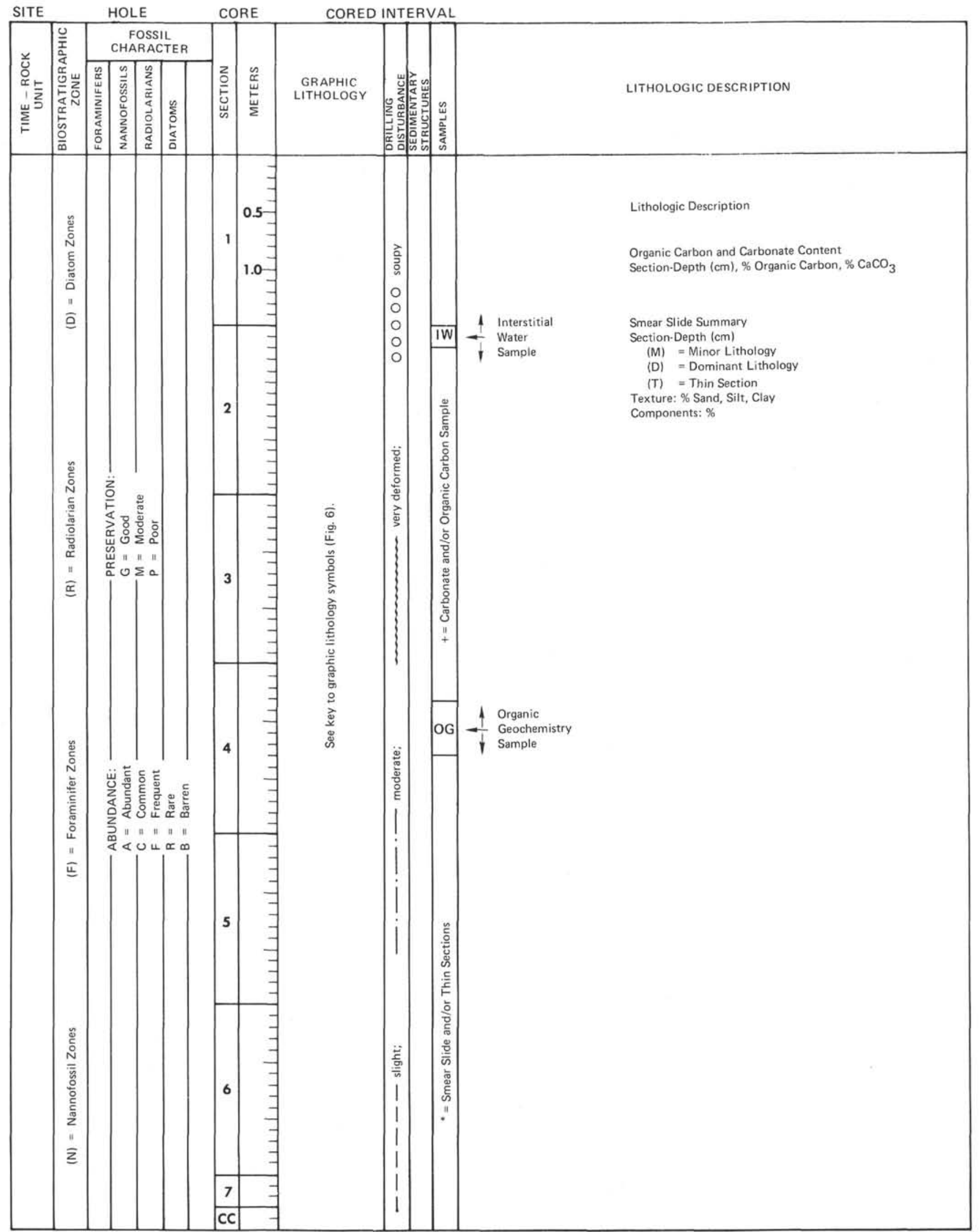

Figure 4. Sample Core Description Form (sediments). 
umn headed "Sedimentary Structures" (Fig. 4); Figure 5 provides the key for these symbols.

Colors of the geologic material are determined by comparison with a Munsell or Geological Society of

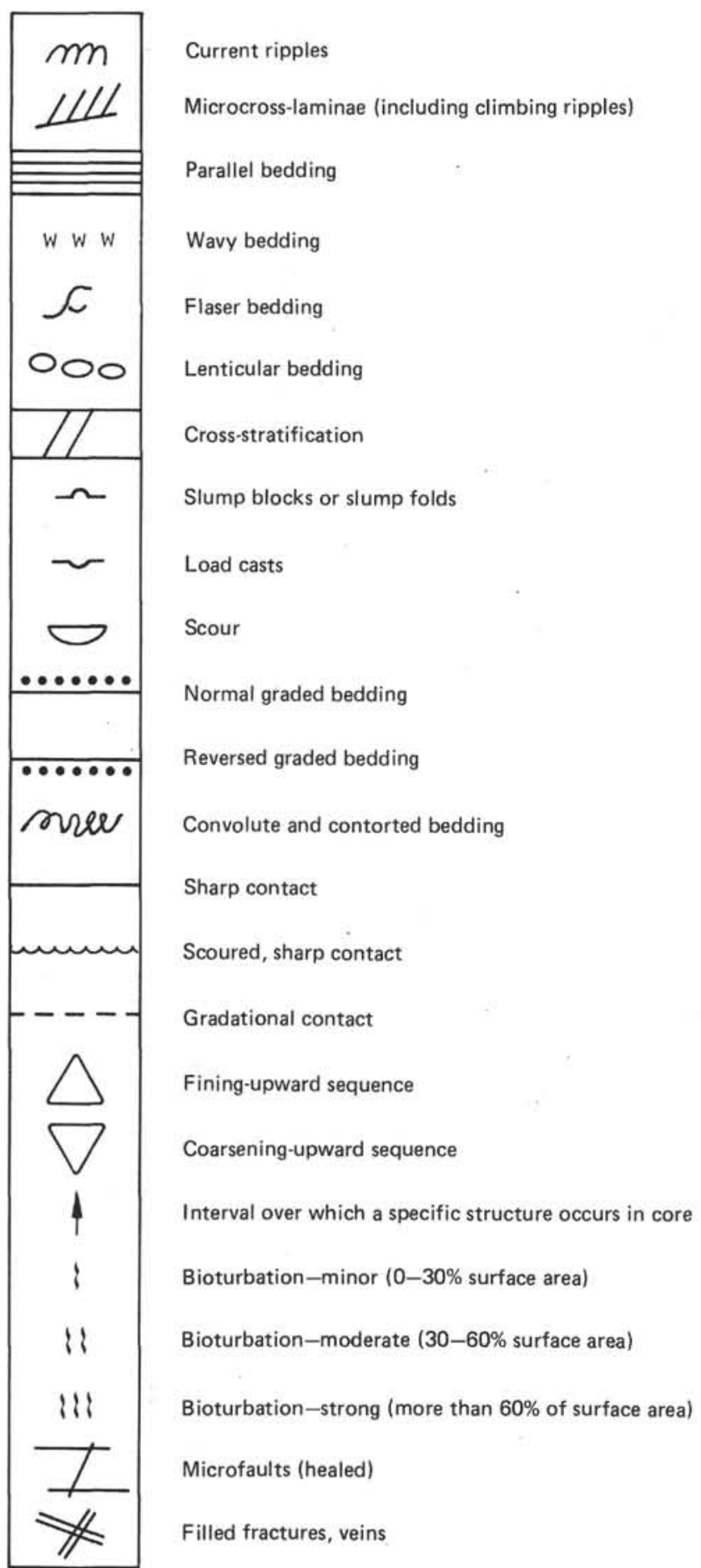

Figure 5. Symbols for sedimentary structures used on the Core Description Form.
America Rock-Color Chart; this is done immediately after splitting the cores (while they are still wet).

The Graphic-Lithology column presented on the Core Description Form depicts lithologies present in each core. These are represented by a single pattern or by a grouping of two or more symbols corresponding to end members of sediment constituents, such as clay or nannofossil ooze. The abundance of any component equals the percentage of the width of the graphic column its symbol occupies.

Because of the difference in the length-to-width ratio between the actual sediment core and the GraphicLithology column, it is not possible to reproduce structures as they actually appeared in the core; rather, they become highly flattened and distorted. The same is true for rock fragments or pebbles in the cores. As a result, the locations of pebbles are shown by a solid square; and the depth of small "patches" of ash, for example, or other lithologic changes are represented by a triangular inset of the appropriate lithologic symbol (Fig. 6) on the right side of the Graphic-Lithology column (this convention applies only to lithologies that do not extend across the entire core).

Format, style, and terminology of the descriptive portion of the Core Description Form (Fig. 4) are not controlled by the Graphic-Lithology column beyond the minimal name assignment, which is derived from the lithologic classification (described later). Colors and additional information such as structures and texture are included in the text portion of the core description.

Smear-slide (or thin-section) compositions, carbonate content $\left(\% \mathrm{CaCO}_{3}\right)$, and organic carbon content determined on board ship are listed below the core description on these forms, where two numbers separated by a hyphen refer to the section and centimeter interval, respectively, of the sample. The locations of these samples in the core and a key to the codes used to identify these samples are given in the column headed "Samples" (Fig. 4). Locations and intervals of organic geochemistry (OG) and interstitial water (IW) samples are also shown in this column.

\section{Lithologic Classification of Sediments}

We used a modified version of the lithologic classification of sediments devised by the JOIDES Panel on Sedimentary Petrology and Physical Properties and adopted by the JOIDES Planning Committee in March $1974 .^{5}$ These modifications, primarily changes in compositional class boundaries of calcareous and siliceous sediments, are explained later in this chapter. This classification is descriptive rather than genetic, and divisions between different types of sediments are somewhat arbitrary. We treat lithologic types not covered in this classification as a separate category termed "Special Rock Types.", A brief outline of the conven-

\footnotetext{
${ }^{5}$ For the unadulterated JOIDES classification, see Volume 42, Pt. 2 of the Initial Reports of the Deep Sea Drilling Project (Ross, Neprochnov, et al., 1978, pp. 13-15).
} 
Siliceous Biogenic Sediments

\section{Soft}

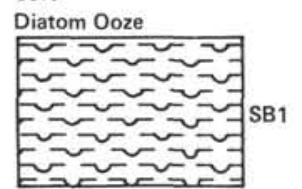

Hard

Diatomite

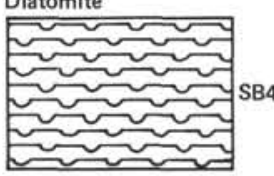

Transitional Siliceous Terrigenous Sediments
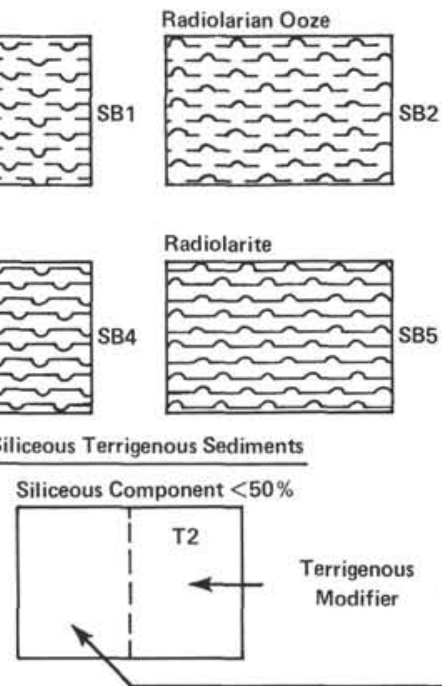

Siliceous Ooze

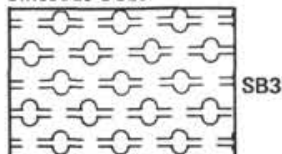

SB3

$=\widetilde{L}=\widetilde{2}=$
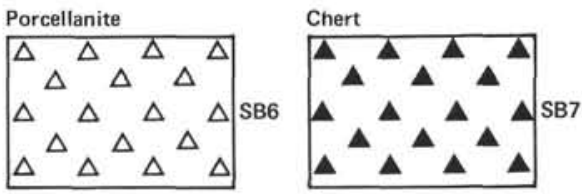

Siliceous Component $>50 \%$
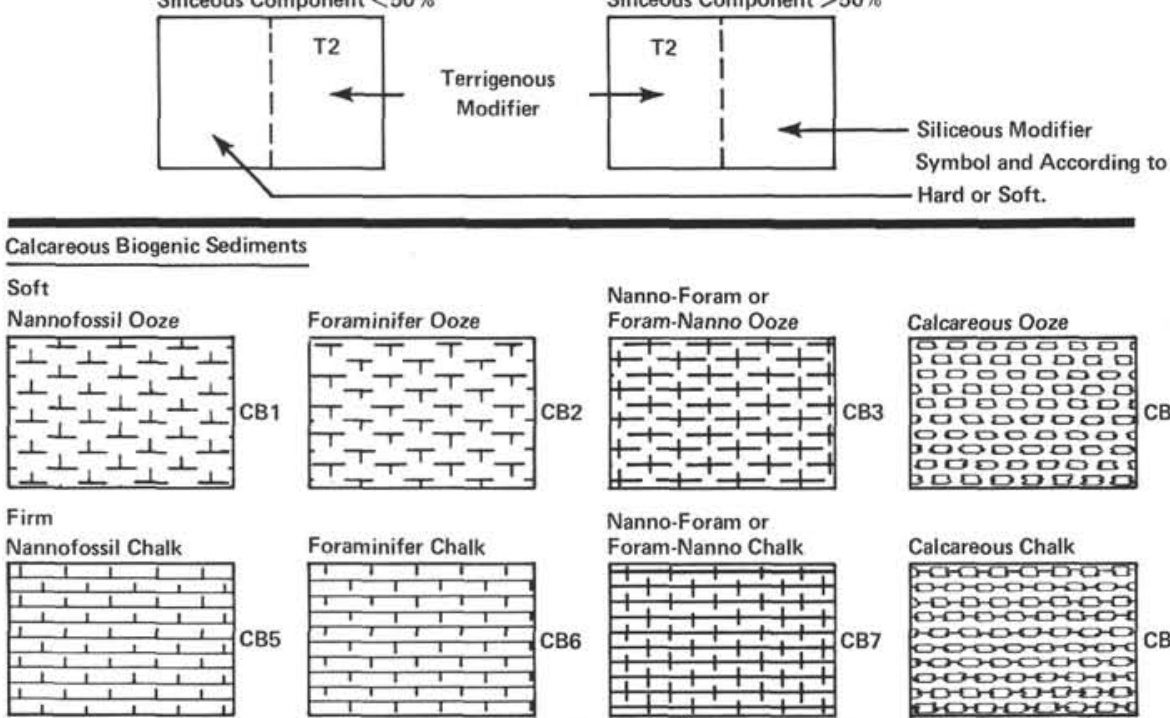

Hard

Limestone
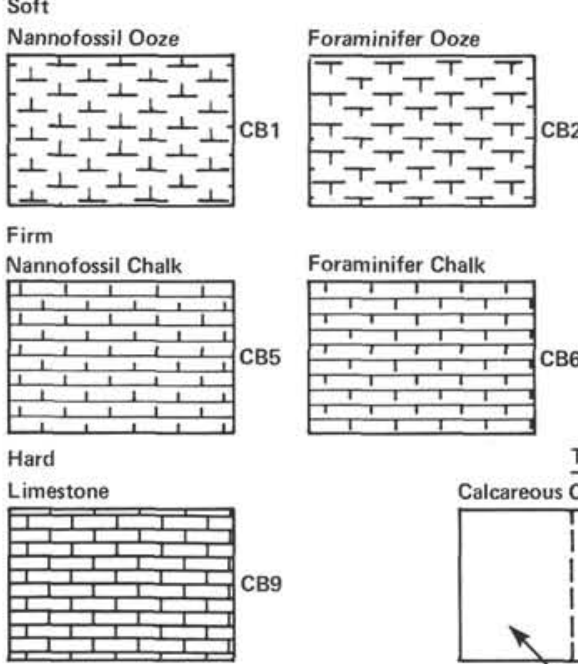

Nanno-Foram or
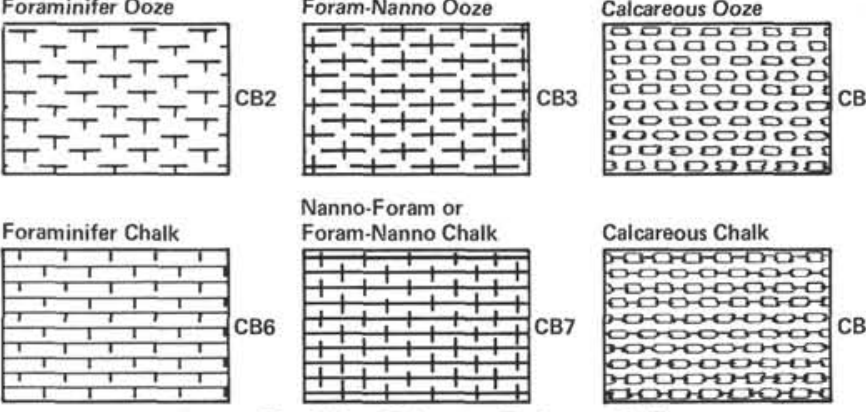

Nanno-Foram or

Foram-Nanno Chalk

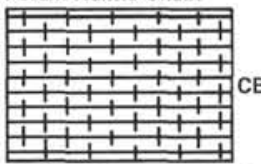

Calcareous Chalk

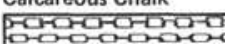

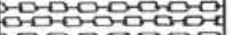

orabarad CB8

posocara

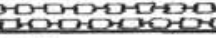

Transitional Calcareous-Terrigenous Sediments

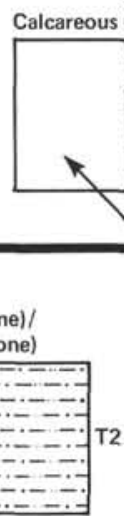

Silty Sand(stone)/

Sandy Silt(stone)
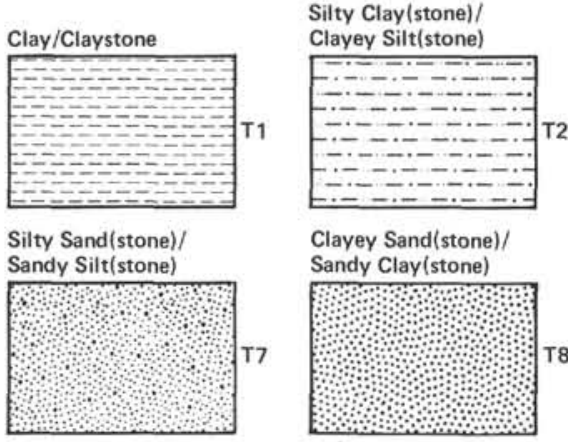

Clayey Sand(stone)/

Sandy Clay(stone)
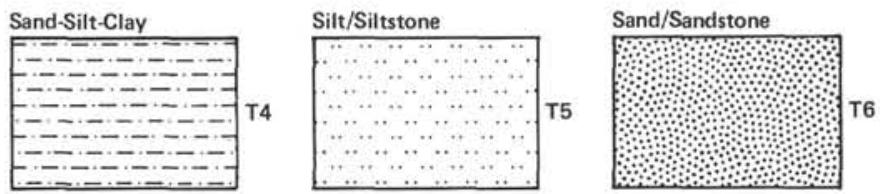

$$
\text { Pyroclastic }
$$

Volcanic Ash (Tuff)
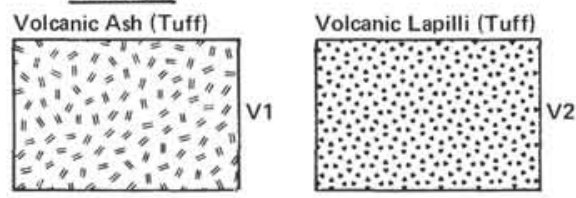

Special Rock Types
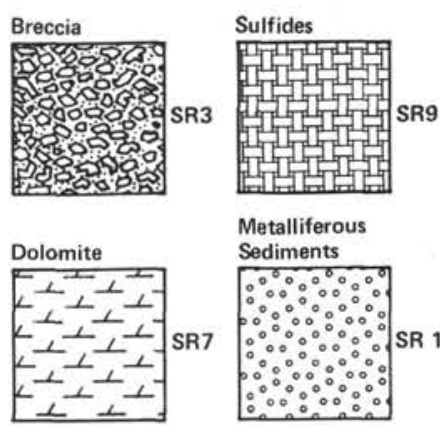

Metalliferous

$\because 00000$ ?

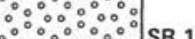

Intermediate

Igneous
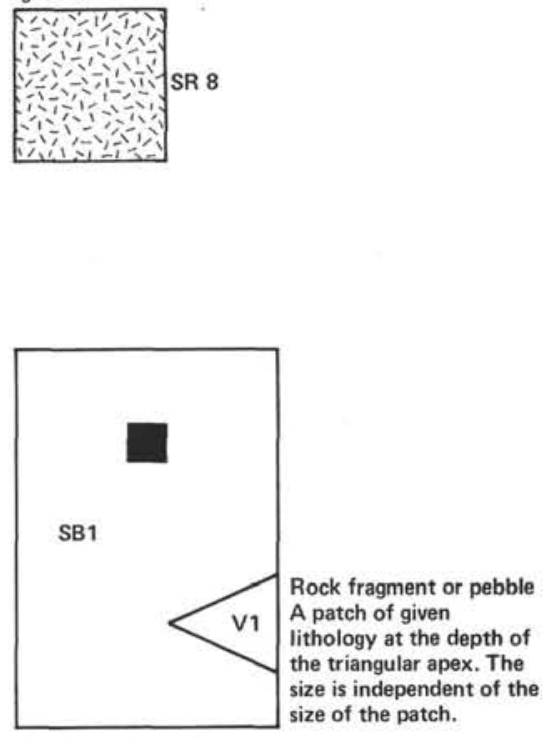

Qualifiers: Letter Overprint

Z = Zeolite

$\mathbf{G}=$ Glauconite
$\mathbf{P}=$ Phosphorite

Calcareous modifier

symbol and according

to hard, firm, or soft.

Dolomite also used as a modifier.
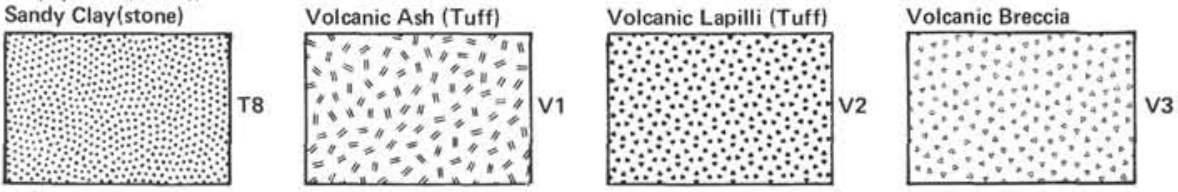

Figure 6. Symbols used in the Graphic-Lithology column of the Core Description Form (sediments). 
tions and descriptive data used to construct this classification follows.

\section{Conventions and Descriptive Data}

\section{Composition and Texture}

In this classification, composition and texture are the only criteria used to define the type of sediment or sedimentary rock. Composition is most important for describing sediments deposited in the open ocean, whereas texture becomes significant for hemipelagic and nearshore sediments. These data come principally from visual estimates of smear slides examined under a petrographic microscope. They are estimates of areal abundance and size components on the slide and may differ somewhat from more accurate analyses of grain size, carbonate content, and mineralogy (see the section on Special Studies). From past experience, quantitative estimates of distinctive minor components are accurate to within $1 \%$ to $2 \%$, but accuracy is poorer for major constituents $( \pm 10 \%)$. All smear-slide estimates were done on board.

Carbonate content is difficult to estimate from smear slides. Therefore, for many cores we determined the percentage of carbonate using the "Karbonat Bombe" technique of Muller and Gastner (1971). This method involves treating a powdered sample with $\mathrm{HCl}$ in a closed cylinder. The resulting pressure of $\mathrm{CO}_{2}$ is proportional to the carbonate $\left(\mathrm{CaCO}_{3}\right)$ content of the sample, and this value is converted to the percentage of $\mathrm{CaCO}_{3}$ using the calibration factor of the manometer. The accuracy of this method is $\pm 5 \%$. Carbonate content determined in this manner is listed on the Core Description Form below the lithologic description.

Textures of sediments estimated from smear slides and listed as sand-silt-clay percentages in the smearslide summary on the Core Description Form include all constituents. Thus a diatomaceous ooze will have a greater percentage of silt-size particles than will a nannofossil ooze because of the different sizes of the tests of the two planktonic groups. This convention causes some confusion when naming terrigenous sediments that contain a significant number of microfossils. For example, a diatomaceous silty clay may have less silt-size terrigenous particles (e.g., quartz and feldspar) than a nannofossil silty clay simply because many diatoms are silt-size and are included as such in the textural estimate. However, we have chosen fairly broad compositional class boundaries (see the following material) for mixed terrigenous and biogenic sediments in order to minimize this effect.

Where applicable, we used one or several modifiers in naming the type of sediment encountered. In all cases the dominant component appears last in the name; minor components precede, with the least common constituent listed first. If minor constituents occur in amounts less than $10 \%$, they are not included in the name. This convention also holds for zeolites, $\mathrm{Fe}-$ and Mn-micronodules, and other indicators of very slow rates of sedimentation or nondeposition, such as fish bones. Often these minerals are conspicuous even though greatly diluted. If deemed important and environmentally significant, as glauconite and phosphorite were on Leg 63, they are sometimes included in the name of the sediment or mentioned in the lithologic description.

\section{Induration of Sediments}

We recognize three classes of induration, or lithification, for calcareous sediments and sedimentary rocks in which the carbonate content is greater than $50 \%$ and only two classes for all other sediments and sedimentary rocks.

1. Calcareous sediments and sedimentary rocks containing $>50 \%$ carbonate (criteria for these categories are after Gealy et al. [1971]):

A. Soft $=$ ooze; has little strength and is readily deformed under pressure of finger or broad blade of spatula.

B. Firm = chalk; is partially lithified and is readily scratched with fingernail or edge of spatula.

C. Hard = limestone; is well-lithified and cemented and resistant to being scratched (or impossible to scratch) with fingernail or edge of spatula.

2. Siliceous sediments (silica $>50 \%$ ).

A. Soft $=$ ooze; is readily deformed by finger or broad blade of spatula.

B. Hard = radiolarite, diatomite, chert, or porcellanite; core must be cut with band saw or diamond saw.

3. Terrigenous sediments (terrigenous components $>50 \%$ ).

A. Soft = sand, silt, clay (or combinations of these); material may be readily deformed by finger or broad blade of spatula.

B. Hard = sandstone, siltstone, claystone, etc. (i.e., suffix "stone" added); core must be cut with band saw or diamond saw.

\section{Types of Sediments and Compositional Class Boundaries}

We distinguish four basic types of sediments: siliceous biogenic sediments, calcareous biogenic sediments, terrigenous sediments, and volcanogenic sediments and pyroclastic rocks. Figure 7 summarizes this classification, except for the volcanogenic sediments. Each type of sediment is discussed briefly in the following sections; an additional category "Special Rock Types"' is also included.

\section{Siliceous Biogenic Sediments}

These are sediments that are composed of at least $50 \%$ biogenic silica or authigenic silica (opal-CT [cristobalite] and/or quartz). If the siliceous component is between $50 \%$ and $90 \%$, then the terrigenous (most abundant textural class, i.e., sand, silt, or clay), calcareous 

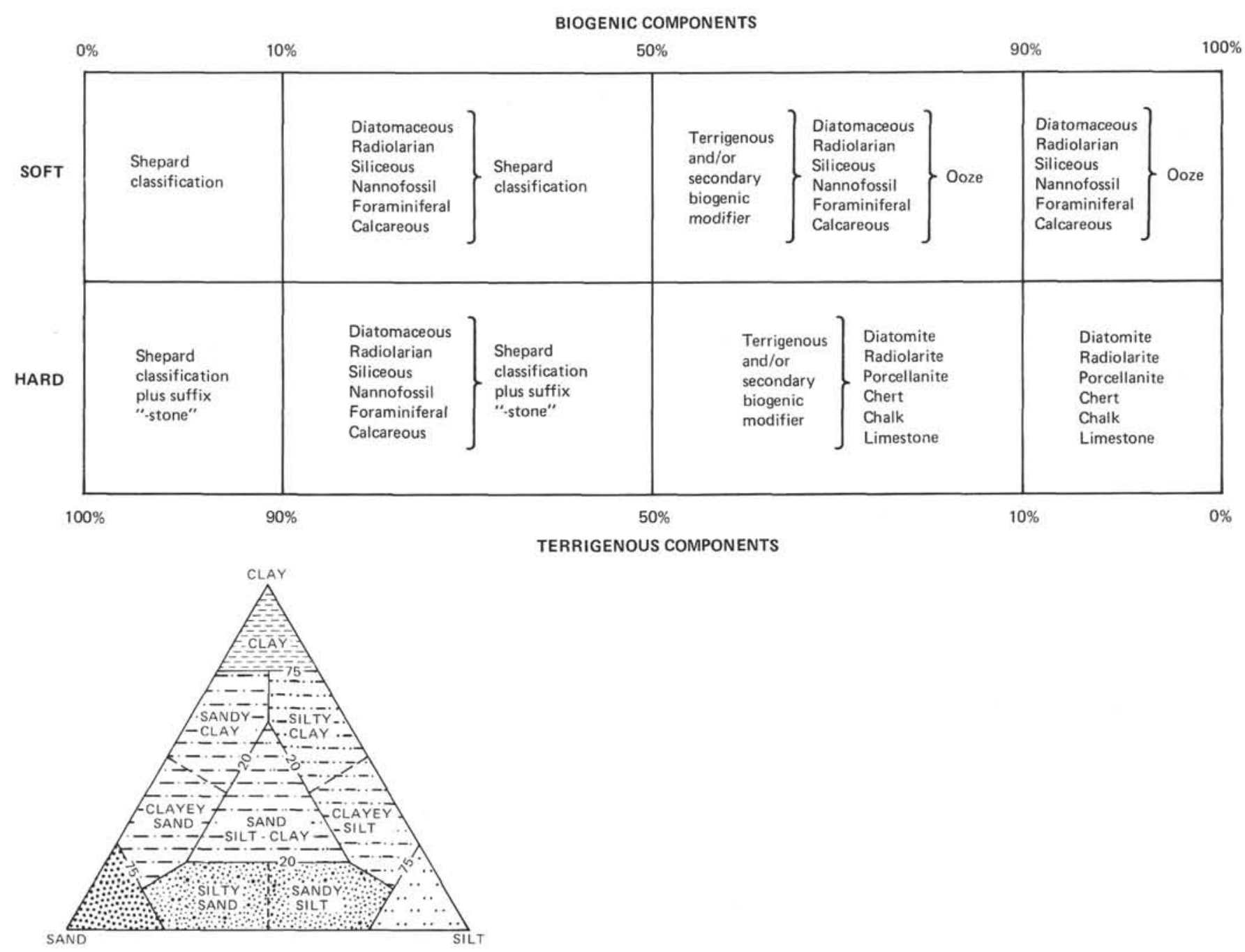

Figure 7. Lithologic classification of sediments used on Leg 63. (Textural classification follows Shepard [1954].)

biogenic, or volcanogenic modifier is retained. For example, clayey diatomaceous ooze describes a soft sediment with at least $10 \%$ clay and between $50 \%$ and $90 \%$ diatoms. If the siliceous component exceeds $90 \%$, then the modifier(s) is dropped. A radiolarian ooze would have $<10 \%$ clay or carbonate and $>90 \%$ radiolarians. If the siliceous biogenic component is between $10 \%$ and $50 \%$, then the names for terrigenous or calcareous biogenic sediments or pyroclastic rocks apply, with the dominant siliceous constituent as a qualifier. Silica in amounts $<10 \%$ is not acknowledged in the name. These terms apply to soft sediments (Fig. 7).

In hard siliceous rocks, siliceous microfossils are often absent. If they have been dissolved and replaced by opal-CT and/or quartz and these minerals make up $>50 \%$ of the rock, then the terms porcellanite and chert apply. We follow the definitions of Taliaferro (1934), Bramlette (1946), and Keene (1975) for these two rocks:

chert: a hard, conchoidally fracturing, varicolored sedimentary rock with semivitreous, vitreous, or waxy luster, which dominantly consists of silica. porcellanite $^{6}$ : a siliceous sedimentary rock with a dull or matte luster resembling that of unglazed porcelain; it is less hard, dense, and vitreous than chert and commonly has a lower silica content.

These definitions differ from previous DSDP usage, which equated cherts with quartzose rocks and porcellanite with rocks in which opal-CT (cristobalite) is the dominant silica mineral. Instead, chert and porcellanite are now considered textural terms independent of the silica mineral present. Recent studies, especially of Neogene siliceous rocks, have shown that rocks that qualify as chert and porcellanite in the textural sense just noted may contain opal-CT and/or quartz and chalcedony. Thus the usage of these terms should not be based on the nature of the silica phase. When used in a textural sense, these terms are helpful field designations.

\footnotetext{
${ }^{6}$ The spelling of porcellanite has been somewhat controversial, Taliaferro (1934) originally proposed the term as "porcelanite." Durham (1974) indicates that the term is deoriginally proposed the term as "porcelanite." Durham (1974) indicates that the term is de-
rived from the Italian "porcellana," however, rather than the English "porcelain." For the sake of consistency, we retain the DSDP spelling.
} 
Qualifiers such as "opal-CT" and "quartzose" may be added when the dominant silica phases are determined by X-ray diffraction or petrographic work.

\section{Calcareous Biogenic Sediments}

These are sediments in which biogenic carbonate or carbonate of indeterminate origin (cement or recrystallized carbonate) composes at least $50 \%$ of the sediment. If the carbonate component is between $50 \%$ and $90 \%$, then the terrigenous, siliceous biogenic, or volcanogenic modifiers are retained. For example, clayey nannofossil ooze describes a soft sediment with at least $10 \%$ clay and between $50 \%$ and $90 \%$ calcareous nannofossils. If the calcareous component exceeds $90 \%$, then the modifiers are dropped. A nannofossil ooze would have $<10 \%$ clay or silica and $90 \%$ calcareous nannofossils. If the calcareous biogenic component is between $10 \%$ and $50 \%$, then the names for terrigenous sediments, siliceous biogenic sediments, or pyroclastic rocks apply, with the dominant calcareous constituent as a qualifier. If carbonate is less than $10 \%$, it is not acknowledged in the name. These terms apply to soft sediments (Fig. 7).

For firm and hard calcareous rocks with carbonate contents $>50 \%$, the terms chalk and limestone, respectively, apply. If the carbonate content is between $50 \%$ and $90 \%$, the terrigenous modifier is retained. For example, a clayey limestone has at least $10 \%$ clay and $50 \%$ to $90 \%$ carbonate. The modifiers are dropped when the carbonate content exceeds $90 \%$. If the carbonate content is less than $50 \%$, the terrigenous, siliceous, biogenic, or volcanogenic names apply, with the dominant carbonate type retained as a qualifier. Carbonate is not acknowledged in the name if it is present in amounts $<10 \%$. Note that we use the qualifier "calcareous" to designate carbonate of indeterminate origin.

\section{Terrigenous Sediments}

The textural classification of terrigenous sediments follows that of Shepard (1954) (Fig. 7), with grain-size limits as defined by Wentworth (1922). Sediments and sedimentary rocks are assigned terrigenous names according to their textural classifications when these components exceed $50 \%$. If the terrigenous component is between $50 \%$ and $90 \%$, the biogenic or volcanogenic modifier is retained. For example, a nannofossil silty clay contains $>10 \%$ calcareous nannofossils and $50 \%$ to $90 \%$ silty clay (with the sand-silt-clay proportions $0-20: 25-50: 50-75)$. The biogenic or volcanogenic modifier is dropped when either component is less than $10 \%$. For hard terrigenous sediments the suffix "stone" is added.

\section{Volcanogenic Sediments and Pyroclastic Rocks}

We arbitrarily distinguish pyroclastic rocks from volcanogenic sediments by using $50 \%$ as the pivotal percentage-pyroclastic rocks have $>50 \%$ volcanic components, volcanogenic sediments $<50 \%$. The textural and compositional classification of Wentworth and Williams (1932) applies to the pyroclastic rocks. Textural groups are:
1) $>32 \mathrm{~mm}$ : volcanic breccia;

2) 4-32 mm: volcanic lapilli (lapilli tuff when indurated); and

3) $<4 \mathrm{~mm}$ : volcanic ash (tuff when indurated)

The compositional breakdown is vitric (glass), crystalline, or lithic, according to the most common constituent. Qualifiers are used when volcanic components are between $50 \%$ and $90 \%$. For example, a clayey vitric ash contains $>10 \%$ clay and $50 \%$ to $90 \%$ ash composed mainly of glass shards. Terrigenous and biogenic modifiers are dropped if $<10 \%$.

When the volcanic component is $<50 \%$, the terminology and class boundaries for terrigenous (and, less often, biogenic) sediments applies. The modifier "tuffaceous" encompasses both ash and lapilli when either or both of these components occur in amounts between $10 \%$ and $50 \%$. Thus a tuffaceous clayey sand(stone) contains $10 \%$ to $50 \%$ ash and/or lapilli and $50 \%$ to $90 \%$ clayey sand.

\section{Special Rock Types}

Special rock categories employed on Leg 63 include:

1) metalliferous sediments: reddish brown iron- and manganese-rich sediments usually overlying basaltic rocks;

2) breccia: fractured and sometimes cemented sediments often containing both sedimentary and volcanic rock types;

3) dolomite: this term is used mainly as a qualifier for clayey sediments containing rhombic carbonate crystals;

4) intermediate igneous rocks: this term specifies andesitic rock fragments (presumably fragments of breccias) recovered at Site 468 ; and

5) sulfide-bearing rocks: chalcopyrite- and sphalerite-bearing rocks overlying basalt at Site 471 .

\section{Special Studies of Sediments}

\section{Organic Carbon and Carbonate Content}

On board the Glomar Challenger, selected samples were measured for organic carbon with the HewlettPackard CHN analyzer. These data are listed on the Core Description Form as "\% Organic Carbon." In addition, we selected samples to be analyzed at the DSDP sediment laboratory on a LECO WR-12 carbon analyzer; these analyses are listed in the Appendix.

\section{Grain-Size Analyses}

Grain-size analyses summarized in the Appendix were made at the DSDP sediment laboratory. The standard sieve and pipette techniques used are described in detail in Bader et al. (1970); modified settling times are from Boyce (1972). Sand, silt, and clay size boundaries follow Wentworth (1922).

\section{Biostratigraphy}

The biostratigraphic framework used during Leg 63 is summarized in Figure 8. The biochronological scale is modified from that of LaBrecque et al. (1977) using the 
recently published $\mathrm{K}-\mathrm{Ar}$ constants of Mankinen and Dalrymple (1979). The Pliocene/Quaternary boundary is that of Haq et al. (1977), the Miocene/Pliocene boundary is from Cita (1975), and the middle/upper Miocene boundary is after Berggren and van Couvering (1974). The planktonic foraminiferal zonation is that of Blow (1969). Bukry's (1975) calcareous nannofossil zonation is used, and correlation to the time scale is in part from unpublished data of J. Barron and D. Bukry. The radiolarian zonation of Wolfart (this volume) is mainly after Hays (1970), Riedel and Sanfilippo (1971, 1978), Moore (1971), Dinkelman (1973), Kling (1973), and Foreman (1975). The diatom zonation is modified from Barron (1976, in press). Low-latitude diatom zones of Burckle $(1972,1977)$ are used at Site 473.

\section{Igneous Rocks}

\section{Visual Core Description Forms}

A rock saw was used to split all igneous rocks into working and archive halves; these were described and sampled on board. Figure 9 shows a composite Visual Core Description Form used for the description of igneous rocks recovered on Leg 63. On this form, each section of a core is described under a set of five column headings: (1) "Piece Number," (2) "Graphic Representation," (3) "Orientation,", (4) "Shipboard Studies," and (5) "Alteration."

In the Graphic-Representation column, each piece is accurately drawn and different features-such as texture, glassy margins, or vesicles-coded according to the symbols given in Figure 10. Two closely spaced horizontal lines in this column indicate the location of styrofoam spacers taped between pieces inside the liner. Beginning with the number 1 , each piece is numbered sequentially from the top of the section (Piece Number column). (Pieces are labeled on the rounded surface rather than the flat slabbed face.) Pieces that fit together before splitting are given the same number but are consecutively lettered as 1A, 1B, 1C, etc. Spacers are placed only between pieces that did not fit together; those pieces are assigned different numbers. In general, spacers may or may not indicate missing (i.e., unrecovered) material between pieces. All cylindrical pieces longer than the diameter of the liner have arrows in the Orientation column, indicating that top and bottom have not been reversed as a result of drilling and recovery. Arrows also appear on the labels of these pieces on both archive and working halves.

The Shipboard-Studies column designates the location and the type of measurements made on a sample on board. The Alteration column indicates the degree of alteration (this code is presented in Fig. 10). Below each set of five descriptive columns is the designation for core and section for which these data apply.
In the right-hand margin of the Visual Core Description Form (Fig. 9), the outline for core descriptions of igneous rocks appears. If more than one core appears on the core form, these data are listed below the description of the first core using the same format. As many cores as space allows are included on one Visual Core Description Form. When space for descriptions is inadequate on this form, these data appear on the following or facing page. In no case, however, does information from one core appear on successive core forms. For each core, the site and core numbers, sections, and depth interval recovered are listed followed by the major and minor rock types and a short description. Thinsection data are tallied below this, then shipboard data.

\section{Classification of Igneous Rocks}

We informally classified igneous rocks recovered on Leg 63 according to mineralogy and texture, determined from visual inspection of hand specimens and thin sections. Standard rock names, such as basalt and diabase, come from mineralogic compositions. Textural terms follow Williams et al. (1954).

\section{Physical Properties}

Boyce (1976b) describes in considerable detail the equipment, methods, and corrections routinely used by shipboard scientists to measure physical properties of sediments and rocks recovered at DSDP sites. On Leg 63 we determined saturated bulk density using the Gamma Ray Attenuation Porosity Evaluator (GRAPE) and the gravimetric technique; we calculated porosity from GRAPE and gravimetric measurements, water content from gravimetric measurements, and sonic velocity using the Hamilton Frame velocity meter. Shear strength of undisturbed sediments was determined following Boyce (1976a). For density and porosity calculations, we assume grain densities of $2.70 \mathrm{~g} / \mathrm{cm}^{3}$ for sediments and $2.90 \mathrm{~g} / \mathrm{cm}^{3}$ for igneous rocks and a corrected pore fluid density of $1.128 \mathrm{~g} / \mathrm{cm}^{3}$.

Plots of the corrected data appear in the Physical Properties section of each site chapter. Listings of these data are available on request from DSDP.

\section{Downhole Logs}

Table 2 lists the specifications of the Gearhart-Owen International wire-line well-logging tools used on Leg 63. All logs were run in the open hole filled with waterbase mud. Lynch (1962) discussed the general theory and applications of the various well-logging instruments. Further detailed treatments are in GearhartOwen (1978), Kokesh (1951), and Kokesh et al. (1965). Plots of Leg 63 logs accompanied by brief discussions appear in the Physical Properties sections of most site chapters. 


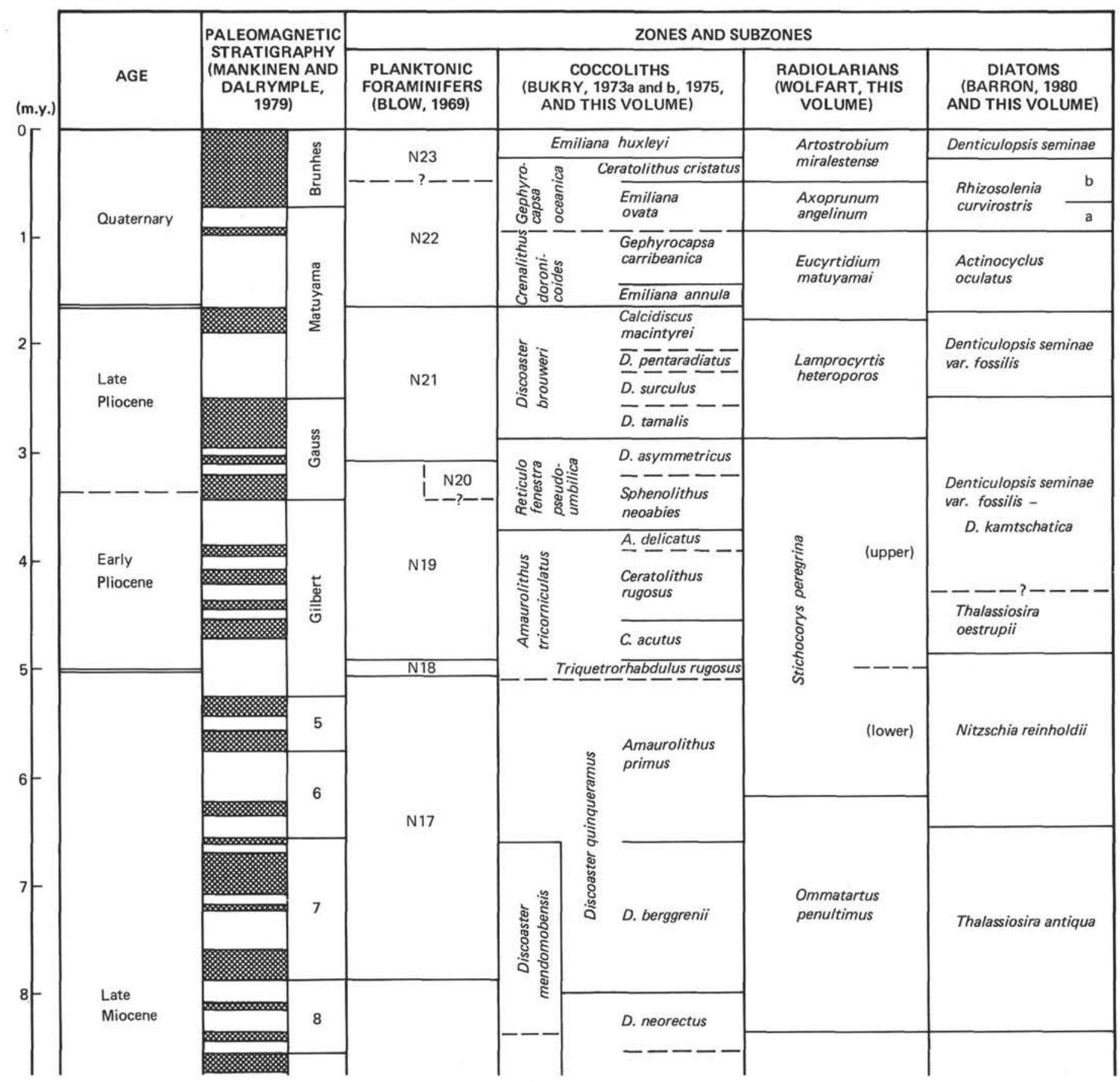




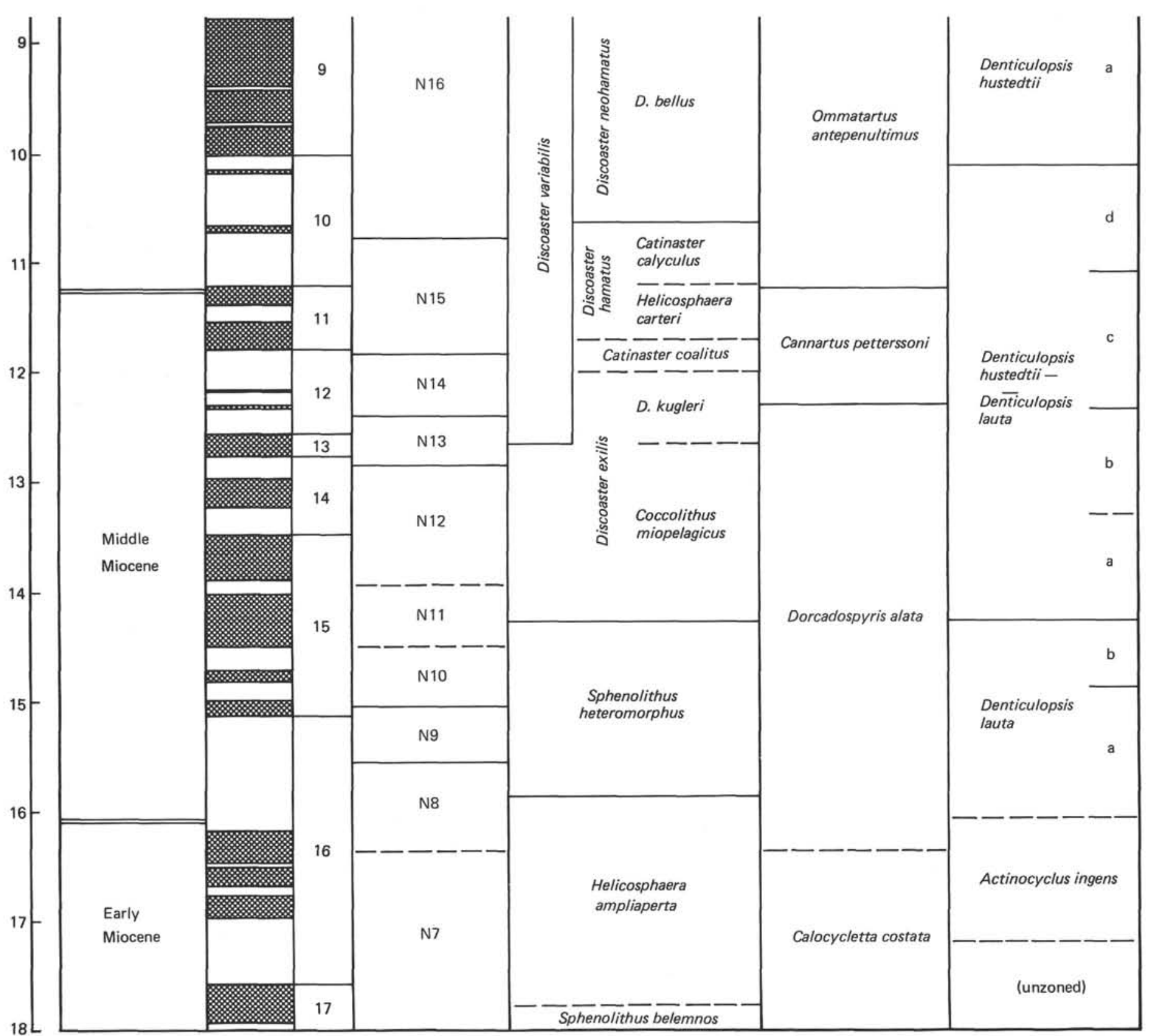

Figure 8. Biostratigraphic framework and time scale used on Leg 63. 


\section{REFERENCES}

Atwater, T., 1970. Implications of plate tectonics for the Cenozoic evolution of western North America. Bull. Geol. Soc. Am., 81: 3513-3536.

Bader, R. G., Gerard, R. D., et al., 1970. Appendix III: Shore-based laboratory procedures. In Bader, R. G., Gerard, R. D., et al., Init. Repts. DSDP, 4: Washington (U.S. Govt. Printing Office), 745-753.

Barron, J. A., 1976. Revised Miocene and Pliocene diatom biostratigraphy of Upper Newport Bay, Newport Beach. Calif. Mar. Micropaleontol., 1:27-63.

, in press. Lower Miocene to Quaternary diatom biostratigraphy of DSDP Leg 57, off northeastern Japan. In Scientific Party, Init. Repts. DSDP, 56, 57, Pt. 2: Washington (U.S. Govt. Printing Office).

Berggren, W. A., and van Couvering, J. A., 1974. The Late Neogene. Palaeogeogr. Palaeoclimatol. Palaeoecol., 16:1-216.

Blow, W. H., 1969. Late Middle Eocene to Recent planktonic foraminiferal biostratigraphy. Proc. Ist Internat. Conf. Planktonic Microfossils, Geneva, 1967, Leiden (E. J. Brill), pp. 199-421.

Boyce, R. E., 1972. Grain-size analyses, Leg 9. In Hays, J. D., et al., Init. Repts. DSDP, 9: Washington (U.S. Govt. Printing Office), 779-798.

1976a. Deep Sea Drilling Project procedures for shear strength measurement of clayey sediment using modified Wykeham Farrance laboratory vane apparatus. In Barker, P. F., Dalziel, I. W. D., et al., Init. Repts. DSDP, 36: Washington (U.S. Govt. Printing Office), 1059-1068.

1976b. Definitions and laboratory techniques of compressional sound velocity parameters and wet-water content, wet-bulk density, and porosity parameters by gravimetric and gamma ray attenuation techniques. In Schlanger, S. O., Jackson, E. D., et al., Init. Repts. DSDP, 33: Washington (U.S. Govt. Printing Office), 931-958.

Bramlette, M. N., 1946. The Monterey Formation of California and the origin of its siliceous rocks. U.S. Geol. Surv. Prof. Paper 212.

Bukry, D., 1975. Coccolith and silicoflagellate stratigraphy, northwestern Pacific Ocean, Deep Sea Drilling Project Leg 32. In Larson, R. L., Moberly, R., et al., Init. Repts. DSDP, 32: Washington (U.S. Govt. Printing Office), 677-701.

Burckle, L. H., 1972. Late Cenozoic planktonic diatom zones from the eastern equatorial Pacific. Beih. Nova Hedwegia, 39:217-246. , 1977. Pliocene and Pleistocene diatom datum levels from the equatorial Pacific. Quat. Res. (N.Y.), 7:330-340.

Cita, M., 1975. The Miocene/Pliocene boundary: history and definition. In Saito, T., and Burckle, L. H. (Eds.), Late Neogene Epoch Boundaries: New York (Micropaleontology Press), pp. 1-30.

Dinkelman, M. G., 1973. Radiolarian stratigraphy: Leg 16, Deep Sea Drilling Project. In van Andel, Tj. H., Heath, G. R., et al., Init. Repts. DSDP, 16: Washington (U.S. Govt. Printing Office), 747-813.

Durham, D. L., 1974. Geology of the southern Salinas Valley. U.S. Geol. Surv. Prof. Paper 819.

Foreman, H. P., 1975. Radiolaria from the North Pacific, DSDP Leg 32. In Larson, R. L., Moberly, R. J.,Jr., et al., Init. Repts. DSDP, 32: Washington (U.S. Govt. Printing Office), 579-676.

Gealy, E. L., Winterer, E. L., and Moberly, R., 1971. Methods, conventions, and observations. In Winterer, E. L., Riedel, W. R., et al., Init. Repts. DSDP, 7, Pt. 1: Washington (U.S. Govt. Printing Office), 9-26.

Gearhart-Owen, 1978. Formation Evaluation Data Handbook: Fort Worth (Gearhart-Owen Industries, Inc.).
Haq, B. U., Berggren, W. A., and van Couvering, J. A., 1977. Corrected age of the Pliocene/Pleistocene boundary. Nature, 269: 483-488.

Hays, J. D., 1970. Stratigraphy and evolutionary trends of radiolaria in North Pacific deep-sea sediments. Geol. Soc. Am. Mem., 126: $185-218$.

Ingle, J. C., Jr., 1973. Summary comments on Neogene biostratigraphy, physical stratigraphy, and paleoceanography in the marginal northeastern Pacific Ocean. In Kulm, L. D., von Huene, R., et al., Init. Repts. DSDP, 18: Washington (U.S. Govt. Printing Office), 949-959.

Keene, J. B., 1975. Cherts and porcellanites from the North Pacific, DSDP Leg 32. In Larson, R. L., Moberly, R. J., Jr., et al., Init. Repts. DSDP, 32: Washington (U.S. Govt. Printing Office), 429-507.

Kleinpell, R. M., 1938. Miocene stratigraphy of California. Am. Assoc. Petrol. Geol., Tulsa, Okla.

Kling, S. A., 1973. Radiolaria from the eastern North Pacific, Deep Sea Drilling Project, Leg 18. In Kulm, L. D., von Huene, R. et al., Init. Repts. DSDP, 18: Washington (U.S. Govt. Printing Office), 617-674.

Kokesh, F. P., 1951. Gamma-ray logging. Oil \& Gas J., 50:284-290.

Kokesh, F. P., Schwartz, R. J., Wall, W. B., et al., 1965. A new approach to sonic logging and other acoustic measurements. $J$. Petrol. Technol., 17:282-286.

LaBrecque, J. L., Kent, D. V., and Cande, S. C., 1977. Revised magnetic polarity time scale for Late Cretaceous and Cenozoic time. Geology, 5:330-335.

Lynch, E. J., 1962. Formation Evaluation: New York (Harper and Row).

Mankinen, E. A., and Dalrymple, G. B., 1979. Revised geomagnetic polarity time scale for the interval 0-5 B.P. J. Geophys. Res., 84: 615-626.

Moore, T., 1971. Radiolaria. In Tracey, J. I., Jr., Sutton, G. H., et al., Init. Repts. DSDP, 8: Washington (U.S. Govt. Printing Office), 727-775.

Müller, G., and Gastner, M., 1971. The "Karbonat-Bombe," a simple device for determination of the carbonate content in sediments, soils and other materials. Neues Jahrb. Mineral Monatsh., 10:466469.

Riedel, W. R., and Sanfilippo, A., 1971. Cenozoic Radiolaria from the western tropical Pacific, Leg 7. In Winterer, E. L., Riedel, W. R., et al., Init. Repts. DSDP, 7, Pt. 2: Washington (U.S. Govt. Printing Office), 1529-1672.

1978. Stratigraphy and evolution of tropical Cenozoic radiolarians. Micropaleontology, 21:61-96.

Ross, D. A., Neprochnov, Y. P., et al., 1978. Init. Repts. DSDP, 42, Pt. 2: Washington (U.S. Govt. Printing Office).

Shepard, F. P., 1954. Nomenclature based on sand-silt-clay ratios. $J$. Sediment. Petrol., 24:151-158.

Sliter, W. V., 1972. Upper Cretaceous planktonic foraminifera zoogeography and paleoecology of eastern Pacific margin. Palaeogeogr. Palaeoclimatol. Palaeoecol., 12:3-31.

Taliaferro, N. L., 1934. Contraction phenomena in cherts. Bull. Geol. Soc. Am., 45:189-232.

Wentworth, C. K., 1922. A scale of grade and class terms of clastic sediments. J. Geol., 30:377-392.

Wentworth, C. K., and Williams, H., 1932. The classification and terminology of the pyroclastic rocks. Rept. Comm. Sedimentation, Bull. Nat. Res. Counc., 80:10-53.

Williams, H., Turner, F. J., and Gilbert, C. M., 1954. Petrography: An Introduction to the Study of Rocks in Thin Section: San Francisco (W. H. Freeman and Co.). 


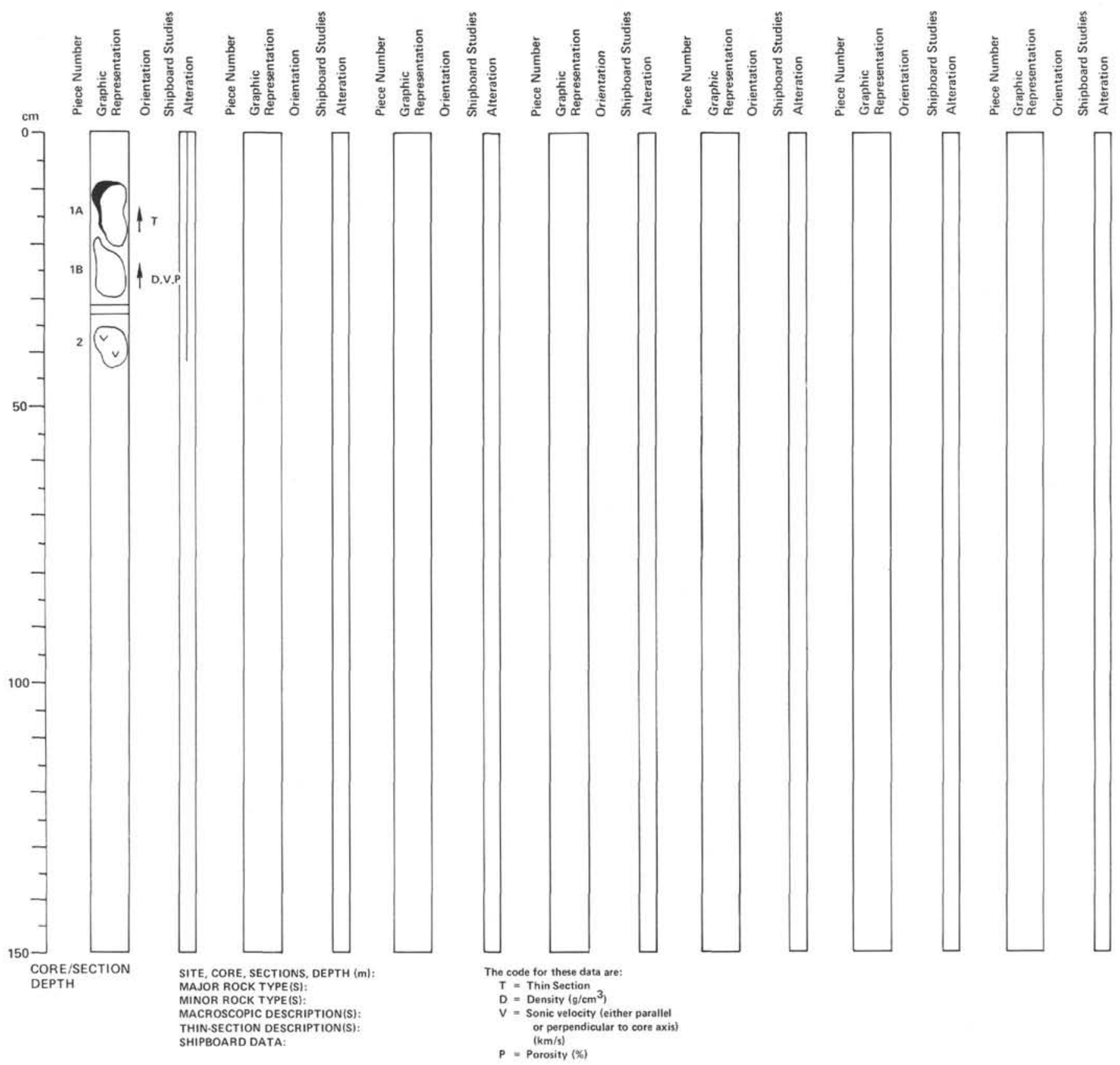

Figure 9. Visual Core Description Form (igneous rocks). 


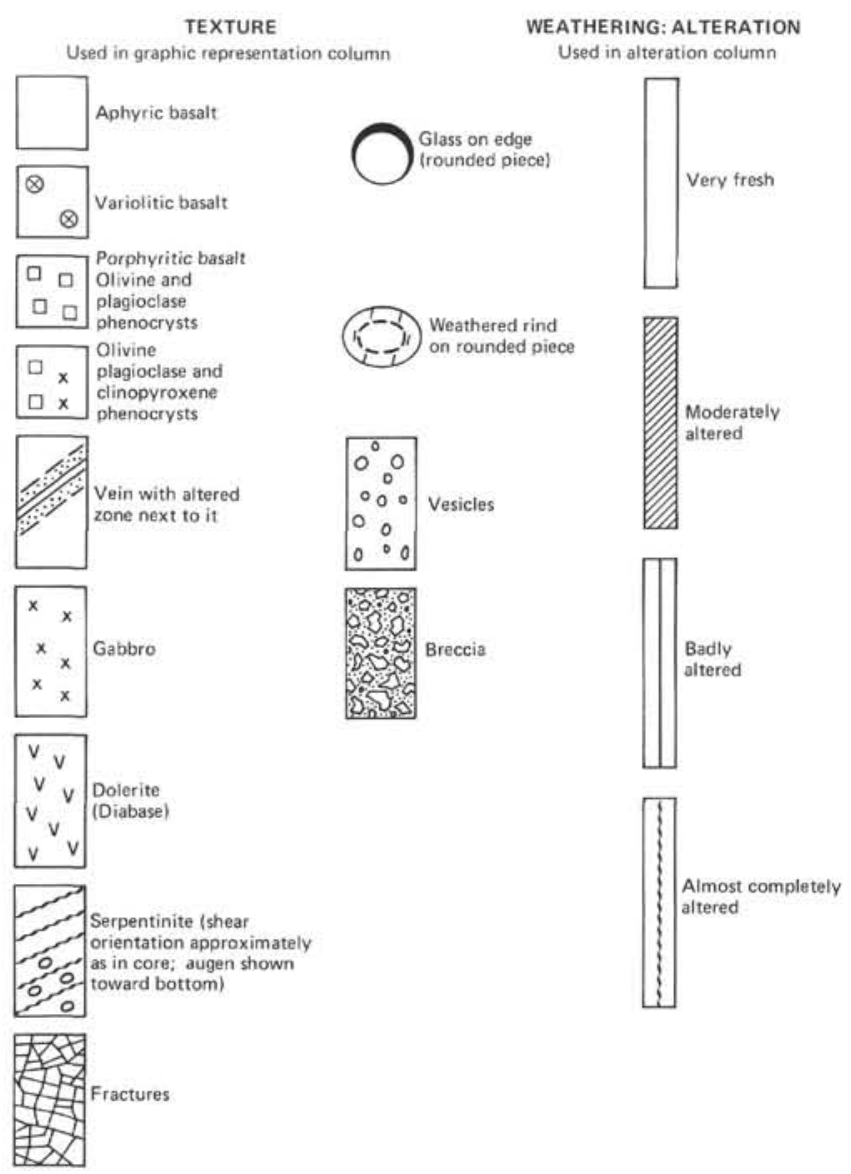

Figure 10. Graphic symbols used on the Visual Core Description Form for igneous rocks.

Table 2. Summary of specifications of Gearhart-Owen well-logging tools, Leg 63.

\begin{tabular}{|c|c|c|c|c|c|c|c|c|}
\hline \multirow[b]{2}{*}{ Tool } & \multicolumn{5}{|c|}{ Tool Specifications } & \multirow[b]{2}{*}{$\begin{array}{c}\text { Log } \\
\text { Rate } \\
(\mathrm{ft} / \mathrm{min})\end{array}$} & \multirow[b]{2}{*}{ Units } & \multirow[b]{2}{*}{ Purpose/Remarks } \\
\hline & $\begin{array}{l}\text { Diameter } \\
\text { (in.) }\end{array}$ & $\begin{array}{l}\text { Length } \\
\text { (ft) }\end{array}$ & $\begin{array}{l}\text { Minimum } \\
\text { Hole Size } \\
\quad \text { (in.) }\end{array}$ & $\begin{array}{l}\text { Maximum } \\
\text { Pressure } \\
\text { (PSI) }\end{array}$ & $\begin{array}{l}\text { Maximum } \\
\text { Temperature } \\
\left({ }^{\circ} \mathrm{F}\right)\end{array}$ & & & \\
\hline $\begin{array}{l}\text { Induction Log (IL) with } \\
\text { Gamma Ray (GR) }\end{array}$ & $3 \%$ & $5-20$ & $3^{15 / 16}$ & 15,000 & 325 & 60 & ohm-m (IL) & resistivity/conductivity \\
\hline $\begin{array}{l}\text { Deep Laterlog (LL) } \\
\text { (with GR) }\end{array}$ & $3 \%$ & $5-20$ & $313 / 16$ & 15,000 & 325 & 35 & ohm-m & resistivity/conductivity \\
\hline $\begin{array}{l}\text { Neutron Log (NL) } \\
\text { (epithermal, neutrons, } \\
\text { noncompensated; with GR) }\end{array}$ & $31 / 2$ & $5-20$ & $3^{13 / 16}$ & 15,000 & 300 & 30 & $\begin{array}{l}\text { API units } \\
\text { (counts/s) }\end{array}$ & porosity \\
\hline Temperature Log (TL) & $1 \% 16$ & $2-5$ & $3^{15 / 16}$ & 15,000 & 300 & 40 & ${ }^{\circ} \mathrm{C}, 3$ & temperature \\
\hline $\begin{array}{l}\text { Compensated Density } \\
\text { Log (CDL) }\end{array}$ & $2 \%$ & $5-8$ & $3^{15 / 16}$ & 15,000 & 215 & 30 & $\mathrm{~g} / \mathrm{cm}^{3}$ & saturated bulk density \\
\hline $\begin{array}{l}\text { Compensated Sonic Velocity } \\
\text { Log (CSVL) with Seismic } \\
\text { Spectrum (SS) and Sonic } \\
\text { Formation Amplitude } \\
\text { Log (SFAL) } \\
\text { Caliper Log (CL) }\end{array}$ & $3 \%$ & $6-11$ & $31 \%$ & 15,000 & 300 & 35 & $\mu \mathrm{s} / \mathrm{ft}$. & $\begin{array}{l}\text { continuous compressional } \\
\text { wave velocity measured } \\
\text { over } 2 \text {-ft interval; fracture } \\
\text { information from } \\
\text { attenuation of SS } \\
\text { hole diameter }\end{array}$ \\
\hline
\end{tabular}

